$\begin{gathered}\text { EPiC Series in Education Science } \\ \text { Volume 1, 2017, Pages 332-340 }\end{gathered}$
$\begin{gathered}\text { AUBEA 2017: Australasian Universities Build- } \\ \text { ing Education Association Conference 2017 }\end{gathered}$

\title{
Modelling User Perception of Online Visualization in Real Estate Marketplaces
}

\author{
O. B. Usuf ${ }^{1}$, M. Takin ${ }^{2}$, M. E. Sepasgozar ${ }^{3}$ \\ ${ }^{1}$ School of Civil \& Environmental Engineering, University of New South Wales (UNSW) \\ ${ }^{2}$ Early Years at UNSW, University of New South Wales \\ ${ }^{3}$ Faculty of Built Environment, University of New South Wales \\ o.usufestudent.unsw.edu.au
}

\begin{abstract}
Increased internet penetration rate has made internet marketing an integral part of real estate industry. This may result in an inefficient process for the buyers and sellers due to the need for physical inspection. The aim of this study is to present key factors influencing the users' decision to use a web-based technology for real estate purposes. This is an ongoing study including two phases: developing a framework based on a case study, and conducting a survey to measure customer perception on incorporating online visualization techniques. The paper presents the result of the first phase evaluating real estate marketing platforms as case studies in Pakistan and Australia. While the initial results show that physical inspections are still required before deciding on property transaction, it was found that the number of inspections can be reduced by incorporating a 3D model of the property to the listing platform. In addition, it was observed that clarity of search results and provision of a 3D model are some of the key factors influencing the user preference to use the website again. This reinforces the idea that advanced visualization techniques can improve the current reliability issues faced by customers and may also streamline the transactions. This study will be extended by conducting the designed survey in two target countries one a developed country and the other one a developing country to compare the most popular features to international customers.
\end{abstract}

Keywords: Online Marketing, Digital Real Estate, Smart Technology, Virtual Reality

\section{Introduction}

Real estate agents bear the most part of the marketing costs during the process of sale and rental from advertisements to arranging buyer inspections and final negotiations. However, they only receive a tiny fraction of marginal selling price. A study based on nearly 100,000 homes, of which roughly 
3,300 were owned by the agent themselves, was carried out in the US. It was found that agent-owned properties sold roughly $3.7 \%$ (or about $\$ 7,600$ at the median price) higher. Also, these properties were listed for 9.5 days (approximately 10\%) longer than comparable non-agent owned ones. While this difference of $\$ 7,600$ is large for the consumers, the real estate agent would only make $1.5 \%$ commission on it, translating to about $\$ 114$. It can be argued that an agent would find it reasonable to forgo the $\$ 114$ to avoid having a client's home on the market an additional ten days (Levitt and Syverson, 2008). The results favored the hypothesis that the real estate agents would be willing to go at lengths to convince clients to execute the transaction quickly and at the non-market value. Furthermore, real estate advertising is at times also designed to be misleading to attract potential buyers. In 2016, an article by Craze (2016) highlights one such scenario where the photographs posted on the website portray a misleading image of the property and the images appear to be tampered with. Such incidents have made customers to doubt the information that is being provided to them until they physically inspect the property themselves (Craze, 2016).

Interestingly, visualization techniques present a unique opportunity to overcome such integrity issues in online real estate marketing. The paper therefore evaluates 'RealEstate', a selected online real estate marketplace in Australia and compares it to 'Zameen', a similar website in Pakistan to study user reception of incorporating visualization tools shows a comparison of key indicators between these two markets. While Australia has a well-developed and well-managed real estate industry, Pakistani market is yet to achieve such development. However, a much larger population and a significantly larger internet user base provides a greater potential benefit for early adopters of visualization techniques in Pakistan compared to the same in Australia.

\begin{tabular}{llll}
\hline & Pakistan & Australia & \\
\hline $\begin{array}{l}\text { Real Estate } \\
\text { Market Size }\end{array}$ & AUD 700 billion (Janjua, 2015). & AUD 6 trillion (Tan, 2016). & \\
\hline Area (km2) & 881,913 (Worldatlas, 2016). & $\begin{array}{l}7,692,024(\text { Geoscience } \\
\text { Australia, }\end{array}$ & \\
\hline Population & $2017,995,540$ (CIA, 2017). & $24,413,700($ ABS, 2016). & \\
\hline Internet users & $34,342,400$ & $\begin{array}{l}20,679,490 \\
\text { (InternetLiveStats, 2016). }\end{array}$ \\
& (InternetLiveStats, 2016). & & \\
\hline
\end{tabular}

\section{Table 1: A comparison of key features of Australia and Pakistan}

\section{Literature Review}

This section reviews the related literature in two principal areas namely; visualization technology and online real estate marketing. While previous studies investigated 3D modelling for various stages of construction including design and asset management, little is mentioned on application of such visualization techniques to online property marketing. A study highlighted the integration of BIM and 3D laser scanning technologies to streamline the user experience in real estate services. The research went on to study the possible synergies of BIM and 3D laser scanning to come up with more comprehensive as-is building data and further advantages of this integration to the real-estate industry (Mahdjoubi et al., 2013). Moreover, the studies have also modelled visualization techniques to simulate inaccessible areas in conflict afflicted regions for urban planning and real estate purposes 
(Far, 2015). Furthermore, researchers have explored the possibility of using mobile phones for creating 3D models and developed a technical framework to incorporate various stereo-based depth hypotheses into a realistic 3D model (Kolev et al., 2014).

The review of previous literature and publications in visualization technologies shows that a lot has been studied on the techniques and their application. However, customer feedback and perception on such applications in online real estate marketplaces and e-commerce has been missed. This paper tends to bridge that knowledge gap by identifying on what is missing in the current online real estate marketplaces and how customers react to the idea of incorporating the advanced visualization techniques.

A study on online real estate marketing conducted in the US during 1999 found that residential properties listed on online marketplaces remained $11 \%$ longer and were sold about $1.93 \%$ more than those not listed online. This translated to roughly six more days of marketing and resulted in a premium of around $\$ 2900$ for the average house. Thus the sellers would benefit the most by listing their properties on the internet (Ford et al., 2005). Furthermore, studies have argued that while the real estate market was experiencing a dramatic rise with about 5.56 million existing single family homes sold just in the US in 2002, the disapproval ratings for the real estate agents were highest compared to any other service providers (Dabholkar and Overby, 2005).

With the increase in internet penetration and globalization, online marketing in real estate business has increasingly become a primary mode of reaching out to consumers. A study in the US concluded that $90 \%$ of consumers did online research before they bought their last home (RealTrends, 2013). Moreover, eighty-six per cent of Australians go online as their major tool to find their next property and nine out of 10 agents use RealEstate and Domain for the advertising (Tan, 2016). A similar trend is also observed in Pakistan where house-hunters are now embracing social media over traditional offline methods for finding their ideal home. Even the overseas Pakistanis are increasingly approaching real estate agents and brokers through social media tools (Asghar, 2015).

Furthermore, the literature shows that websites can be evaluated and compared from a variety of perspectives to increase its efficiency (Delone and McLean, 2003, Joyce and Lin, 2004). One way to study these could be based on a customer satisfaction perspective i.e. whether the website has been built with customers' goals in mind (Chanaron, 2005). Alternatively, the evaluation could also be based the perspective of web designers and measure the factors that they considered to be important when designing or developing effective websites (Tan and Tung, 2003).

The two-phased research investigates customers' preferences and perception on integrating visualization tools such as immersive 3D models to online real estate marketplaces. At this phase, the online marketplaces selected as two the cases are evaluated across four attributes namely; content, design, organization, and user-friendliness as identified by researchers (Hasan and Abuelrub, 2011). This proposed framework of measurement attempts to strike a balance between contemporary market practices and multiple reference disciplines and focus on quantifiable features and indicators that at present found in successful websites.

\section{Methodology}

This research will be conducted in two main phases:(1) initial review of case websites based on criteria outlined by Hasan and Abuelrub (2011); (2) developing a survey for measuring users' 
perception. This paper focuses on evaluating a selected case platform by focusing on attributes revolving around customer perception of using online visualization techniques in real estate marketplaces.

In first phase, we developed a framework consisting of four major categories which were then subdivided into quantifiable variables as illustrated in Error! Reference source not found.. The two selected websites were compared over these factors. The first phase of this study focuses on quantifying the features of both websites based on perception of expert customers in Australia. Each participant chosen was an experienced user and had at least 3 experiences of using the website(s) for renting/buying in the last three years.

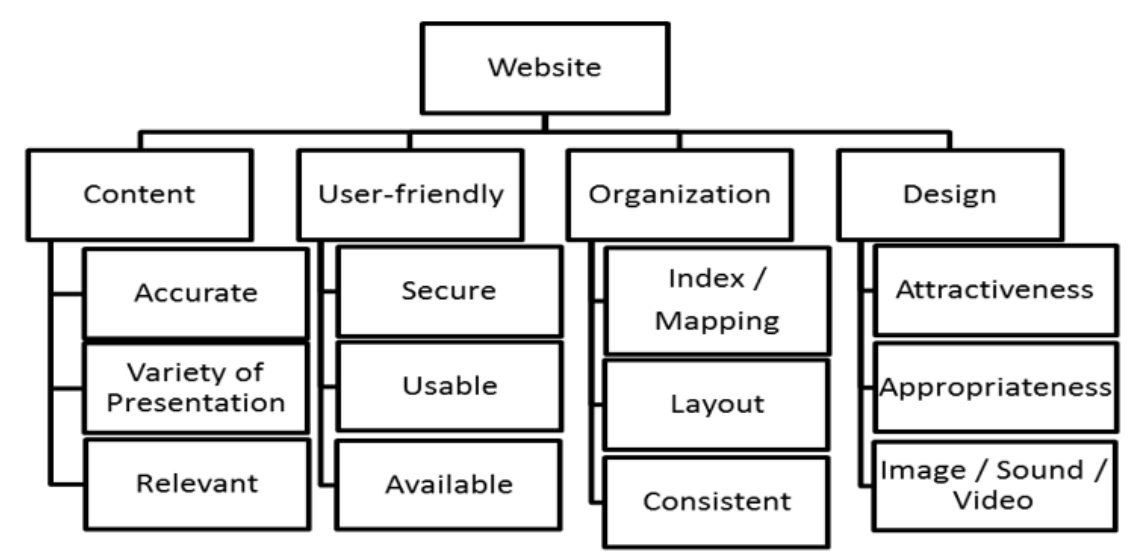

Figure 1 An initial framework for evaluating websites

According to Statstool (2016), a popular website statistic and SEO reporting portal, Zameen boasts a daily unique visitor count of over 7,900 and daily page views amounting to roughly 34,500 (StatsTool, 2016b). Similarly, it measures daily unique visitor count and daily page views for RealEstate to be around 44,700 and 233,700, respectively (StatsTool, 2016a). shows case profiles for each website.

\begin{tabular}{lll}
\hline Attributes & Case 1: Zameen & Case 2: RealEstate \\
\hline $\begin{array}{l}\text { Specific } \\
\text { Property } \\
\text { Information }\end{array}$ & $\begin{array}{l}\text { Advertisements include seller details, } \\
\text { images, property features, business \& } \\
\text { communication features } \\
\text { (broadband/cable tv access), map, } \\
\text { nearby places, finance calculator, } \\
\text { trends, agent contact form, related }\end{array}$ & $\begin{array}{l}\text { Advertisements include seller details, } \\
\text { general/outdoor features, images, floor } \\
\text { plans \& interactive tours, map, } \\
\text { inspection/auction time, nearby } \\
\text { schools, suburb profile \& market data, } \\
\text { email form to contact seller/agent, } \\
\text { tools \& calculator. }\end{array}$ \\
& Properties, forums, blogs, maps, & Buy, rent, invest, sold, share (links to \\
\hline \multirow{2}{*}{ Service } & &
\end{tabular}




\begin{tabular}{lll}
\hline Category & trends, index & $\begin{array}{l}\text { partner site), new homes, retire, find } \\
\text { agents, lifestyles, news, commercial } \\
\text { (links to partner site) }\end{array}$ \\
\hline $\begin{array}{l}\text { Search } \\
\text { Property } \\
\text { Type }\end{array}$ & $\begin{array}{l}\text { Houses, flats, portions, farm houses, } \\
\text { plot files, agricultural, residential } \\
\text { plots, commercial plots, industrial, } \\
\text { plot forms }\end{array}$ & $\begin{array}{l}\text { House, apartments \& unit, townhouse, } \\
\text { villa, land, acreage, rural, blocks of } \\
\text { units, retirement livings }\end{array}$ \\
\hline $\begin{array}{l}\text { Search } \\
\text { Refinements }\end{array}$ & $\begin{array}{l}\text { Search can be narrowed down based } \\
\text { on location, price, area, number of } \\
\text { bedrooms, financing options, agent } \\
\text { type, and verification status. }\end{array}$ & $\begin{array}{l}\text { Search can be narrowed down based } \\
\text { on location, price, area, number of } \\
\text { bedrooms, car spaces, indoor/outdoor } \\
\text { features and eco-friendly. }\end{array}$ \\
\hline $\begin{array}{l}\text { Search } \\
\text { Results } \\
\text { Presenting }\end{array}$ & $\begin{array}{l}\text { Results are displayed in form of list } \\
\text { and can be sorted based on price, area } \\
\text { and verification status. }\end{array}$ & $\begin{array}{l}\text { Results are displayed in form of list, } \\
\text { map or on a calendar. Sorting can be } \\
\text { done based on price, date and suburb. }\end{array}$ \\
\hline
\end{tabular}

Table 2: Case Profile of the two cases being considered in the

The study will be extended by conducting the survey in the second phase which is not covered in this paper. It is supposed to recruit customers and measure their perception in two selected countries. The designed questionnaire will include a total of twenty questions based on the Contents, User Friendliness, Organization and Design.

\section{Results of case evaluation}

A head to head comparison of Zameen and RealEstate was initially made to study the service offering of both the web portals. It was observed that each website provided similar information specific to property for each listing. Furthermore, while RealEstate provided a separate tab for detailed property floor plans, Zameen provided the basic floorplans as one of the images in the listing since Pakistani consumers may be less interested in technically detailed floor plans. Additionally, it was observed that Zameen was more comprehensive in service offering as it included information on commercial and industrial properties while RealEstate would link to partner sites like "RealCommercial" for Commercial Properties.

Interestingly, service offerings of both sites were organized in a different manner. Zameen focused on different needs of a single user and organized services based on the needs. For example, a user could use "Property" page to search for any type of property, or go to "Blogs" tab for curated contents by the Zameen team. While RealEstate organized services based on individual needs of different consumer groups for example, a separate page dedicated to for property rentals ad separate for selling properties. Elements of localization were observed in both cases, such as the search refinement by RealEstate allowed users to narrow search based on indoor/outdoor features of the property. On the other hand, Zameen allowed users to narrow down search results by choosing only properties from trusted/verified real estate agents.

Next the two cases were analyzed across four selected attributes namely Content, Organization, Design and User-friendliness. Important findings of the study are shown in 


\begin{tabular}{|c|c|c|c|}
\hline Attribute & Case 1: Zameen & Case 2: RealEstate & $\begin{array}{l}\text { Advantages of } \\
\text { Visualization } \\
\text { Technologies }\end{array}$ \\
\hline \multirow[t]{2}{*}{ Content } & $\begin{array}{l}\text { Mechanism to verify } \\
\text { details of ad by website. } \\
\text { Is costly and time } \\
\text { consuming. }\end{array}$ & $\begin{array}{l}\text { Only user details of } \\
\text { advertisers are verified } \\
\text { however content is not } \\
\text { verified. }\end{array}$ & $\begin{array}{l}\text { Automated } \\
\text { verification process } \\
\text { that compares the } \\
\text { information listed } \\
\text { with 3D Model }\end{array}$ \\
\hline & $\begin{array}{l}\text { Limited to English and } \\
\text { "Urdu" Language. }\end{array}$ & Limited to English only. & $\begin{array}{l}\text { Users can extract } \\
\text { information from 3D } \\
\text { model without much } \\
\text { reading of the text }\end{array}$ \\
\hline \multirow[t]{2}{*}{ Design } & $\begin{array}{l}\text { Advertisements are } \\
\text { cluttered all over the } \\
\text { website with a } \\
\text { prominent premium } \\
\text { advertisement banner } \\
\text { on the top of the } \\
\text { website. }\end{array}$ & $\begin{array}{l}\text { Less cluttered as } \\
\text { considerably less } \\
\text { advertisement which are } \\
\text { featured at the middle or } \\
\text { in the bottom of page. }\end{array}$ & $\begin{array}{l}\text { Observing user } \\
\text { behavioral patterns on } \\
\text { a 3D model can allow } \\
\text { target advertising } \\
\text { allowing a more } \\
\text { attractive and less } \\
\text { cluttered website. }\end{array}$ \\
\hline & $\begin{array}{l}\text { The website uses less } \\
\text { visuals to for a faster } \\
\text { browsing. }\end{array}$ & $\begin{array}{l}\text { Large banner images are } \\
\text { used as being less } \\
\text { graphic intensive is not a } \\
\text { concern. }\end{array}$ & $\begin{array}{l}\text { Images can be cut } \\
\text { down and replaced by } \\
\text { a single } 3 \mathrm{D} \text { model } \\
\text { with option to scale } \\
\text { the resolution to allow } \\
\text { speedier browsing. }\end{array}$ \\
\hline \multirow[t]{2}{*}{ Organization } & $\begin{array}{l}\text { Details provided in each } \\
\text { listing are highly } \\
\text { variable. }\end{array}$ & $\begin{array}{l}\text { Details provided in each } \\
\text { listing vary to a lesser } \\
\text { extent. }\end{array}$ & $\begin{array}{l}\text { 3D models will allow } \\
\text { consistent information } \\
\text { as the user can "see" } \\
\text { the property. }\end{array}$ \\
\hline & $\begin{array}{l}\text { Basic search tools to } \\
\text { filter the results to } \\
\text { user's criteria. }\end{array}$ & $\begin{array}{l}\text { Optimized search engine } \\
\text { that allows user to refine } \\
\text { the search to a much } \\
\text { finer level. }\end{array}$ & $\begin{array}{l}\text { Use of 3D model can } \\
\text { cut down the search } \\
\text { time and allow a } \\
\text { speedier transaction. }\end{array}$ \\
\hline User Friendly & $\begin{array}{l}\text { No interactive features } \\
\text { offered in design of } \\
\text { website. }\end{array}$ & $\begin{array}{l}\text { The website offers a VR } \\
\text { solution but it is limited } \\
\text { to static } 2 \mathrm{D} \text { pictures. }\end{array}$ & $\begin{array}{l}\text { 3D model may allow } \\
\text { user to plan to move } \\
\text { into the property as } \\
\text { they can calculate cost } \\
\text { of furnishing. }\end{array}$ \\
\hline
\end{tabular}

\section{Table 3: Comparison of Zameen and RealEstate}

shows that both websites suffer from similar set of issues. These issues, particularly those related to the content can be resolved by incorporation of advanced visualization technologies such as using $3 \mathrm{D}$ model. This model is equipped with a pattern recognition program to identify user's buying behavior based on previous local searching practices by other users. This is a smart $3 \mathrm{D}$ model which also can provide valuable quantitative data sets to the owner in an automated manner. The smart property visualization system (SPVS) gives the possibility for interactive inspections which allow international 
users to visit their selected properties. At the same time, the potential buyers can estimate dimensions and volumes of the property for future carpeting, flooring and furnishing.

To support the findings of the case analysis, a group of 12 experienced users were interviewed and asked questions from four categories namely content, organization, design and user-friendliness.

The responses of the experts indicated that while the user opinion was largely positive on Userfriendliness and Content attributes of the online marketplaces, their perception on Organization and Design quality was less so. Around a fifth of the participants were strongly disagreeing to disagreeing with the standard of information/content available on these websites. Moreover, the analysis also explored the relationships between the variables identified in Error! Reference source not found. and the user preference based on responses provided by the experienced users. shows correlation between some key variables such as the clearly presented results and the reduced need to inspect the property physically. It is noteworthy to mention that the user's preference to use the website again was strongly correlated with the integration of $3 \mathrm{D}$ model in website to improve reliability. The participants' response to future use of website was also strongly positively correlated to the clarity of the search results.

\begin{tabular}{llc}
\hline & Variable & Correlation Coefficient \\
\hline $\begin{array}{l}\text { Search results presented } \\
\text { clearly }\end{array}$ & Less need to inspect property & 0.80 \\
\hline Easy to use & Less need to inspect property & 0.84 \\
\hline Provides accurate information & Will recommend the website to others & 0.96 \\
\hline $\begin{array}{l}\text { Adding 3D Model will make } \\
\text { information more reliable }\end{array}$ & I will use the website in future & 0.90 \\
\hline I will use the website in future & Search results presented clearly & 0.92 \\
\hline
\end{tabular}

\section{Table 4: Correlation Coefficients for Key Variables}

Experts' feedback was also collected over the reliability of information available on their choice of real estate website. Only two participants were satisfied that current websites did not need any improvement, while the rest of them suggested use of new visual options. Half of participants also highlighted that real estates should provide higher level of details on their websites.

In addition, the participants suggested that by adding a 3D model the reliability of the website can be improved. This reinforces the idea that advanced visualization techniques such as a 3D model will be required to improve the current reliability issues faced by users. It may also stream line the transactions by reducing the need to physically inspect the properties. Therefore, the visualization quality should be determined in next phase.

\section{Conclusion}

This paper addresses a clear gap in the literature of real estate marketing. The paper aims to investigate the customers' perceptions of using a web-based visualization technology for real estate business. The lack of reliability and consistency of property information available online means the constant need to inspect properties physically. This is an ongoing study including two phases: 
developing a framework based on a case study, and conducting a survey to measure customer perception on incorporating online visualization techniques. The paper presented the result of evaluating real estate marketing platforms as case studies in Pakistan and Australia. The case analysis of the two-leading online real estate marketplaces in Australia and Pakistan shows that each website offers similar array of features. The analysis also shows that the current platforms suffer from similar set of issues such as verification of property advertisements. These can be resolved by integration of visualization technologies. The analysis is supplemented by conducting interviews with experienced users to gauge customer perception and preference. The participants verified that the current web platforms should be revised using advanced visual options to develop the smart property visualization system (SPVS). In addition, it is stressed that SPVS should provide high level of details on their websites. Additionally, the participants suggested that by adding a 3D model the reliability of the website can be improved. It was observed that clarity of search results and provision of a 3D model are some of the key factors influencing the user preference to use the website again. This reaffirms that users can overcome reliability issues and streamline transactions if advanced visualization techniques are integrated into the current online real estate marketplaces. Also, this study will be extended by conducting a survey on a larger set of consumers in Australia and in Pakistan and to evaluate customer perceptions on technology integration.

\section{References}

ABS. 2016. "Population clock" [Online]. Australian Bureau of Statistics website. Commonwealth of Australia.

Available: http://www.abs.gov.au/ausstats/abs@.nsf/94713ad445ff1425ca25682000192af2/1647509ef7 e25faaca2568a900154b63?OpenDocument [Accessed December, 15 2016].

ASGHAR, H. 2015. Increasing Trend of Social Media in Real Estate Business. Available from: http://blog.opus.com.pk/2015/07/03/increasing-trend-of-social-media-in-real-estate-business/ [Accessed January 15 2017].

CHANARON, J. Evaluating e-learning: the case of automative small-medium suppliers. Proceedings of the 1st International Conference on e-Business and E-learning (EBEL), Amman, Jordan, 2005. 13-25.

CIA. 2017. Pakistan [Online]. March 17. Available: https://www.cia.gov/library/publications/theworld-factbook/geos/pk.html [Accessed 2017].

CRAZE, K. 2016. Is this photo a legitimate marketing trick or misleading advertising? [Online]. news.com.au. Available: http://www.news.com.au/finance/real-estate/buying/this-pic-hasjust-created-a-22000-headache-for-the-agent-and-vendor/newsstory/51c76f364c8ad1cd34313ebba3bb7f05 [Accessed January 17 2017].

DABHOLKAR, P. A. \& OVERBY, J. W. 2005. Linking process and outcome to service quality and customer satisfaction evaluations: An investigation of real estate agent service. International journal of service industry management, 16, 10-27.

DELONE, W. H. \& MCLEAN, E. R. 2003. The DeLone and McLean model of information systems success: a ten-year update. Journal of management information systems, 19, 9-30.

FAR, M. S. D., CARLOS MARMOLEJO 2015. Does 3D Information Modeling Give Better Vision To Deal With Future Real Estate Capacities of Inaccessible Areas Within Conflict Zones? : European Real Estate Society (ERES).

FORD, J. S., RUTHERFORD, R. C. \& YAVAS, A. 2005. The effects of the internet on marketing residential real estate. Journal of Housing Economics, 14, 92-108. 
GEOSCIENCE AUSTRALIA, A. G. 2017. Australia's Size Compared [Online]. Available: http://www.ga.gov.au/scientific-topics/national-location-information/dimensions/australiassize-compared [Accessed May 12 2017].

HASAN, L. \& ABUELRUB, E. 2011. Assessing the quality of web sites. Applied Computing and Informatics, 9, 11-29.

INTERNETLIVESTATS. 2016. Internet Users by Country (2016) [Online]. Available: http://www.internetlivestats.com/internet-users-by-country/ [Accessed January 5 2017].

JANJUA, S. 2015. Magnitude of Real Estate Sector in Pakistan [Online]. Available: http://www.abnamro.com.pk/2015/02/03/magnitude-real-estate-sector-pakistan/ [Accessed].

JOYCE, D. \& LIN, O. 2004. Critical success factors for online auction web sites. Proceedings of the 17th NACCQ.

KOLEV, K., TANSKANEN, P., SPECIALE, P. \& POLLEFEYS, M. Turning mobile phones into 3d scanners. Proceedings of the IEEE Conference on Computer Vision and Pattern Recognition, 2014. 3946-3953.

LEVITT, S. D. \& SYVERSON, C. 2008. Market distortions when agents are better informed: The value of information in real estate transactions. The Review of Economics and Statistics, 90, 599-611.

MAHDJOUBI, L., MOOBELA, C. \& LAING, R. 2013. Providing real-estate services through the integration of $3 \mathrm{D}$ laser scanning and building information modelling. Computers in Industry, 64, 1272-1281.

REALTRENDS. 2013. The 2013 Online Performance Study [Online]. RealTrends.com. Available: https://www.realtrends.com/store/index.php?route=product/product\&product_id $=84$ [Accessed March 24 2015].

STATSTOOL. 2016a. RealEstate.com.au Web Stats,Analysis,Ranking And Seo Report [Online]. Available: http://realestate.com.au.statstool.com/ [Accessed December 11 2016].

STATSTOOL. 2016b. Zameen.com Web Stats,Analysis,Ranking And Seo Report [Online]. Available: http://zameen.com.statstool.com/ [Accessed December 11 2016].

TAN, F. B. \& TUNG, L. Exploring website evaluation criteria using the repertory grid technique: A web designers' perspective. 2003. AIS.

TAN, S.-L. 2016. Digital disruption comes to the property market [Online]. Australian Financial Review. Available: http://www.afr.com/real-estate/digital-disruption-comes-to-the-propertymarket-20160128-gmfoze\#ixzz4dBF17nln [Accessed].

WORLDATLAS. 2016. Where is Pakistan? [Online]. Worldatlas.com. Available: http://www.worldatlas.com/as/pk/where-is-pakistan.html [Accessed April 13 2017]. 